\title{
Myc family oncoproteins function through a common pathway to transform normal cells in culture: cross-interference by Max and trans-acting dominant mutants
}

\author{
Bhaskar Mukherjee, Sharon D. Morgenbesser, and Ronald A. DePinho ${ }^{1}$ \\ Department of Microbiology and Immunology, Albert Einstein College of Medicine, Bronx, New York 10461 USA
}

\begin{abstract}
The myc family of cellular oncogenes encodes three highly related nuclear phosphoproteins (c-Myc, N-Myc, and L-Myc) that are believed to function as sequence-specific transcription factors capable of regulating genes important in cellular growth and differentiation. Current evidence indicates that Myc family proteins exist as biologically active heterodimeric complexes in association with another helix-loop-helix leucine zipper phosphoprotein, Max. We have investigated the common and unique properties among the Myc family, as well as the physiological role of Max in the regulation of Myc family function. We demonstrate that trans-activation-incompetent mutants of one Myc family member can act in trans to dominantly suppress the cotransformation activities of all three Myc oncoproteins, indicating that the Myc family functions through common genetic elements in its cellular transformation pathways. Employing coimmunoprecipitation with either anti-Myc or anti-Max antibodies, we show that the transfected normal c-Myc, N-Myc, and L-Myc oncoproteins associate with the endogenous Max protein in REF transformants, indicating that the Max interaction represents at least one component common to Myc family function. In addition, we observed a striking reduction in Myc cotransformation activity when a Max expression construct was added to myc/ras cotransfections. We discuss these biological findings in the context of a proposed model for Myc/Max function and regulation in which Max serves as either an obligate partner in the Myc/Max transcriptional complex or as a repressor in the form of a transcriptionally inert Max/Max homodimer capable of occupying Myc/Max-responsive gene targets.
\end{abstract}

[Key Words: Myc family; Max; cotransformation; dominant interference; Myc/Max complexes]

Received March 16, 1992; revised version accepted May 1, 1992.

Three highly related nuclear phosphoproteins, c-Myc, $\mathrm{N}-\mathrm{Myc}$, and L-Myc, are encoded by the myc family of cellular oncogenes. Although their exact function has not been determined, current evidence suggests that Myc oncoproteins act as sequence-specific transcription factors that serve to regulate genes important in normal cellular growth and differentiation processes (for review, see Lüscher and Eisenman 1990; DePinho et al. 1991). Deregulated expression of all three myc family genes has been implicated in the genesis or progression of naturally occurring tumors and has contributed to transformation of cultured cells as well as tissues in transgenic mice (for review, see Moroy et al. 1991). In the rat embryo fibroblast (REF) cotransformation assay, c-myc, N-myc, or L-myc expression constructs have been shown to cooperate with the activated $\mathrm{H}$-ras (val12) gene to transform

${ }^{1}$ Corresponding author. early-passage REFs (Land et al. 1983; Schwab et al. 1985; Yancopoulos et al. 1985; DePinho et al. 1987a,b; Legouy et al. 1987; Birrer et al. 1988). In this assay, c-myc appears to be most oncogenically active, whereas $\mathrm{N}-\mathrm{myc}$ and L-myc exhibit moderate and weak transforming activity, respectively (DePinho et al. 1987a,b). The tumor distribution of each myc family member is also different and appears to correlate strongly with their tissue-specific expression during normal development (Nisen et al. 1986; Zimmerman et al. 1986).

Structural studies have led to a better understanding of the function of Myc oncoproteins in normal cellular growth and malignant transformation. Domains essential for transcriptional trans-activation (Kato et al. 1990), sequence-specific DNA binding (Blackwell et al. 1990; Halazonetis and Kandil 1991; Kerkhoff et al. 1991; Prendergast and Ziff 1991), protein oligomerization (Blackwood and Eisenman 1991; Prendergast et al. 1991; Kato et al. 1992), and nuclear localization (Stone et al. 1987; 
Dang and Lee 1988) have been found to be highly conserved among c-Myc, N-Myc, and L-Myc proteins (DePinho et al. 1986, 1987a,b). The carboxy-terminal regions of Myc proteins contain two structural motifs identified previously in known transcription and differentiation factors, namely, the leucine zipper (LZ; Landschulz et al. 1988) and the basic region/helix-loop-helix (BR/HLH; Murre et al. 1989). The two motifs are found in a contiguous arrangement, with the LZ located at the carboxyl terminus and the HLH just amino-terminal to the LZ. A region rich in basic amino acid residues that overlaps the amino-terminal end of the HLH motif appears to confer sequence-specific DNA-binding activities to the hexameric core sequence CACGTG in vitro (Blackwell et al. 1990; Blackwood and Eisenman 1991; Prendergast et al. 1991). The BR/HLH and LZ structures have been found to be indispensable for polypeptide dimerization with the Myc-associated human protein Max (Blackwood and Eisenman 1991) and its murine homolog, Myn (Prendergast et al. 1991). In vitro affinity chromatography studies have demonstrated that Max can homodimerize, or heterodimerize with c-Myc, N-Myc, or L-Myc (Blackwood and Eisenman 1991). The formation of a heterodimeric complex between either c-Myc (Blackwood et al. 1992; Kato et al. 1992) or N-Myc (Wenzel et al. 1991) and Max has also been substantiated in vivo. Max appears to have the capacity to form Max/Max homodimers in vitro (Blackwood and Eisenman 1991) and possibly in vivo (Kato et al. 1992). Myc/Max heterodimers and Max/Max homodimers appear to have similar DNA sequence-binding specificities in vitro (Prendergast et al. 1991; Kato et al. 1992). Although c-Myc homodimers do not appear to exist in vivo (Smith et al. 1990), homodimer formation can be forced at high protein concentrations in vitro (Dang et al. 1989; Smith et al. 1990).

The amino-terminal region of the c-Myc protein has been shown previously to be essential for neoplastic transformation (Stone et al. 1987) and appears to be involved in trans-activation (Kato et al. 1990). This region has been found to be highly conserved among all members of the Myc family from lower vertebrates to humans (N. Schreiber-Agus and R.A. DePinho, in prep.). In contrast, Max does not exhibit trans-activation activity (Kato et al. 1992).

Activities of LZ/HLH-containing proteins have been found to be strongly dependent on dimerization (Lassar et al. 1989). This requirement forms the basis for dominant interference, a stratagem first proposed by Herskowitz (1987), which is designed to generate a null phenotype for proteins whose function relies on oligomerization. In this respect, the overexpression of a mutant Myc oncoprotein that lacks its trans-activation domain but still retains its ability to oligomerize would be expected to behave as a dominant-negative mutant of the normal Myc oncoprotein regardless of the specific oligomerization partner of that protein. Recent experiments with c-Myc appear to have demonstrated the effectiveness of this approach (Dang et al. 1989).

Although all three Myc family proteins exhibit oncogenic activity, it is not clear whether differences in their oncogenic potency and tumor distribution result from differences in their trans-activation activities or their affinities for Max or specific gene targets. In this study we show that dimerization-competent/trans-activation-incompetent c-Myc, N-Myc, and L-Myc mutants can all interfere equally with the transformation activities of either c-Myc or N-Myc in the REF cotransformation assay, indicating that Myc family oncoproteins share common genetic elements in their transformation pathways. Consistent with previous in vivo studies for c-Myc (Blackwood et al. 1992; Kato et al. 1992) and N-myc (Wenzel et al. 1991), we demonstrate that the transfected c-Myc, N-Myc, and L-Myc oncoproteins associate with the endogenous Max protein in REF transformants, indicating that the Max interaction represents at least one component common to Myc family function. In addition, the neutralizing activity for each mutant myc expression construct was equivalent, suggesting that differences in oncogenic potency among Myc oncoproteins may localize to regions important for trans-activation rather than those involved in sequence recognition and dimerization. Finally, the finding that a max expression vector functioned to suppress the transformation activity of all three myc family genes has led to a model for the regulation of Myc activity.

\section{Results}

Cross-interference among the Myc family of cellular oncoproteins by trans-acting dominant mutants

To determine whether c-Myc, N-Myc, and L-Myc function through common or distinct cellular transformation pathways, mutant c-Myc, N-Myc, and L-Myc oncoproteins were assayed for their ability to influence the cotransformation activities of oncogenically active c-Myc and N-Myc. All three mutant proteins, termed c-Zip, N-Zip, and L-Zip, encode BR/HLH and LZ sequences responsible for sequence-specific DNA-binding activity and protein oligomerization but contain large deletions in the highly conserved trans-activation domain as defined previously in the c-Myc protein (Kato et al. 1990) (Fig. 1). These zip expression constructs were not oncogenically active (data not shown). Employing the REF cotransformation assay, the oncogenic potency of each Myc + Zip combination was measured by parameters standardly used to establish the degree of malignant transformation, including the rate of foci formation, the subcloning efficiency of harvested foci, and the ability of established cell lines to exhibit anchorage-independent growth.

The zip-induced phenotype For each transfection point, a Rous sarcoma virus/long terminal repeat (RSV/ LTR)-driven c-myc or $\mathrm{N}$-myc gene and an activated $\mathrm{H}$-ras (val12) gene were cotransfected onto a monolayer of early-passage REFs in the presence or absence of c-zip, $\mathrm{N}$-zip, or L-zip expression constructs. In several experiments, the number of foci generated by c-myc/ras alone or by $\mathrm{N}-\mathrm{myc} / \mathrm{ras}$ alone was markedly reduced when a c-zip, N-zip, or L-zip expression construct was added to 


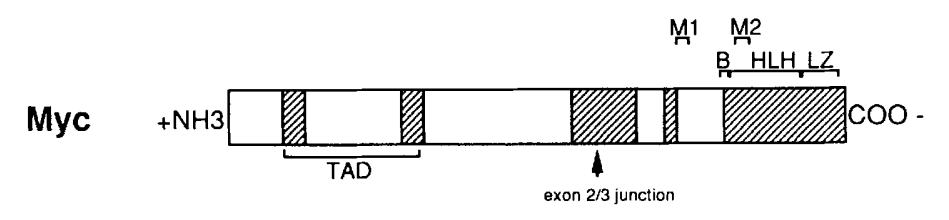

Figure 1. Schematic of c-myc, N-myc, and L-myc dominant-negative mutant (zip) expression constructs. (Top) A linear representation of a Myc family protein. Highly conserved regions among the Myc family proteins are indicated by the crosshatched regions, and the major structural-functional regions are bracketed with the abbreviations, which indicate the following: (TAD) trans activation domain; (M1, M2) nuclear localization signals; (B) basic region; (HLH) helix-loop-helix; (LZ) leucine zipper. In the diagrams of the three dominant-negative mutant constructs, the highly conserved regions are crosshatched, and the boundaries of the deleted domains are indicated by restriction enzyme sites used and corresponding amino acid residues united in the ligation. Solid arrows and rectangles represent the RSV/LTR and SV40 polyadenylation sequences, respectively.

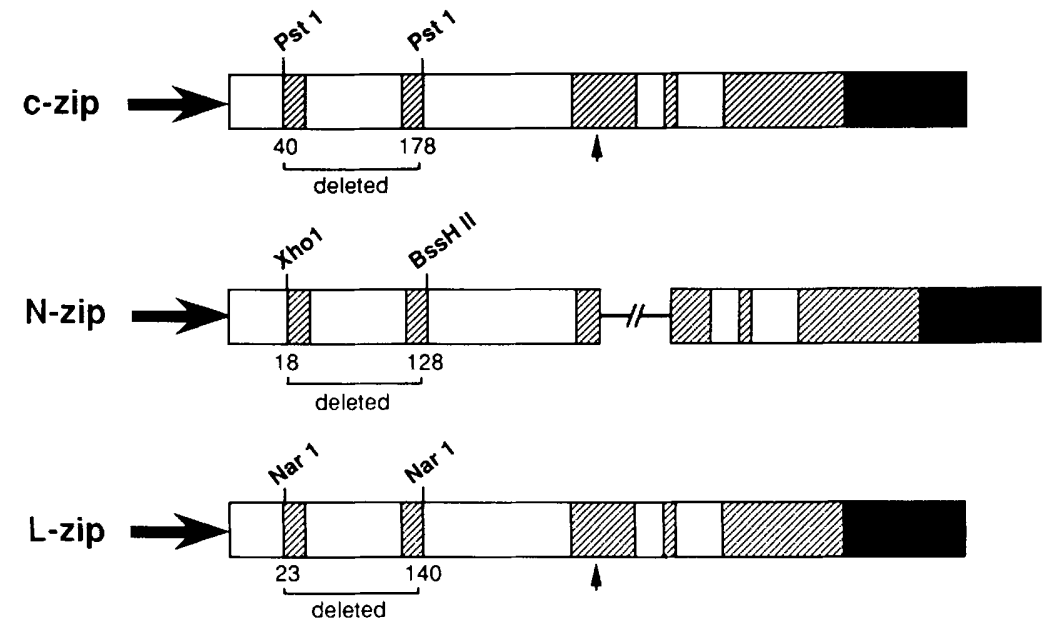

the cotransfection (Fig. 2, A and B, c-myc and N-myc, respectively). Most notably, all three zip expression constructs were found to be nearly equivalent in their capacity to attenuate c-myc/ras and $\mathrm{N}-m y c /$ ras transformation activity. Specifically, relative to c-myc/ras alone, an average reduction in foci generated was $18 \%$ for c-zip, $13 \%$ for N-zip, and $20 \%$ for L-zip. Similar results were obtained in $\mathrm{N}-$ myc/ras assays, wherein a $14 \%$ reduction was observed with c-zip, $20 \%$ with $\mathrm{N}$-zip, and $23 \%$ with L-zip. The suppressive activity of each zip expression construct was readily evident with other parameters used to assess the degree of malignant transformation, including a decreased potential for anchorage-independent growth and a decreased efficiency of subcloning, that is, the ability of harvested foci to become established as permanent cell lines (Fig. 2A,B). Because L-myc transforms weakly, we did not assay the impact of zip expression constructs on L-myc cotransformation activity because differences would be more difficult to detect.

Zip does not affect E1A cotransformation activity To determine whether the actions of Zip are restricted to Myc transformation activity, we tested the ability of the zip expression constructs to influence the oncogenic activities of the adenovirus ElA viral oncoprotein. In two experiments the addition of either c-zip or L-zip to E1A/ ras cotransfections was found to have no effect on the degree of foci formation (Fig. 2C). These results suggest that zip-induced suppression operates through elements that are essential and specific for Myc family activities and that ElA functions through a pathway that is not dependent on Myc function.

$L-M y c$ repression of $c-M y c$ and $N-M y c$ To validate further the experimental approach and the findings of the zip experiments, we took advantage of the oncogenic po- tency differences among the myc family. The weakly transforming L-myc gene was tested for its ability to influence the oncogenic activities of the more potent c-myc or $\mathrm{N}$-myc genes. The addition of L-myc would be expected to induce a phenotype similar to the zip-induced phenotype, albeit less pronounced because unlike the zip constructs L-myc can cooperate to some extent with ras to transform REFs. In four experiments, the addition of an equimolar amount of the L-myc construct to c-myc/ras or $\mathrm{N}-m y c /$ ras cotransfections resulted in a level of cooperation activity that was intermediate between c-myc or N-myc, and L-myc activities (Fig. 2D). Northern analysis demonstrated that all transformants from the various combination expressed high levels of the introduced c-myc, N-myc, L-myc, and ras genes (data not shown).

Expression analysis in the transformed REF cell lines Steady-state mRNA levels for the various transfected constructs were examined in a large number of c-myc/ ras-transformed cell lines that were generated in the presence or absence of the various zip expression vectors; a representative panel of samples is presented in Figure 3. All permanently established cell lines were found to express high levels of the $2.0-\mathrm{kb}$ transcript encoded by the transfected c-myc gene (Fig. 3A,B, c-myc panels, lanes $1-32$ | relative to levels of $c-m y c$ gene expression found in the P19 mouse embryonal carcinoma cell line, a cell line that serves as a control for the levels of myc family gene expression typically observed in developing mouse tissues (Fig. 3A, B, P19 lanes). All transformed cell lines were also found to express high steadystate mRNA levels of the introduced $\mathrm{H}$-ras gene (Fig. 3A, H-ras panel, lanes 1-15; similar results were observed for samples 16-32; data not shown). Significantly, when the 
A

\begin{tabular}{|l|c|c|c|c|}
\hline \multirow{2}{*}{ Transfected DNA } & \multicolumn{2}{|c|}{ Total \# of Foci } & $\begin{array}{l}\text { Subcloning Efficiency = } \\
\text { \# of established cell lines/ } \\
\text { \# of cell lines tested (\%) }\end{array}$ & $\begin{array}{l}\text { Anchorage-independent } \\
\text { cells / cell lines tested (\%) }\end{array}$ \\
\cline { 2 - 5 } C-myc + ras & Exp. 1 & Exp. 2 & $10 / 12(83 \%)$ & $8 / 9(89 \%)$ \\
c-myc + ras + c-zip & 260 & 290 & $10 / 17(59 \%)$ & $9 / 15(60 \%)$ \\
c-myc + ras + N-zip & 38 & 36 & $6 / 11(55 \%)$ & $6 / 10(60 \%)$ \\
c-myc + ras + L-zip & 48 & 62 & $5 / 10(50 \%)$ & $4 / 9(44 \%)$ \\
\hline
\end{tabular}

B

\begin{tabular}{|l|c|c|c|}
\hline \multirow{2}{*}{ Transfected DNA } & \multicolumn{2}{|c|}{ Total \# of Foci } & $\begin{array}{l}\text { Subcloning Efficiency }= \\
\text { \# of established cell lines/ } \\
\text { \# of cell lines tested (\%) }\end{array}$ \\
\cline { 2 - 3 } & Exp. 1 & Exp. 2 & 130 \\
N-myc + ras & 126 & 130 & $9 / 13(69 \%)$ \\
N-myc + ras + c-zip & 20 & 16 & $6 / 11(55 \%)$ \\
N-myc + ras + N-zip & 24 & 28 & $6 / 10(60 \%)$ \\
N-myc + ras + L-zip & 30 & 28 & $5 / 14(36 \%)$ \\
\hline
\end{tabular}

C

D

\begin{tabular}{|l|c|c|}
\hline \multirow{2}{*}{ Transfected DNA } & \multicolumn{2}{|c|}{ Total \# of Foci } \\
\cline { 2 - 3 } & Exp. 1 & Exp. 2 \\
\hline E1a + ras & 910 & 920 \\
E1a + ras + c-zip & 840 & 870 \\
E1a + ras + N-zip & ND & ND \\
E1a + ras + L-zip & 760 & 801 \\
\hline
\end{tabular}

\begin{tabular}{|c|c|c|c|c|c|c|}
\hline \multirow{2}{*}{ Transfected DNA } & \multicolumn{4}{|c|}{ Total \# of Foci } & \multirow{2}{*}{$\begin{array}{l}\text { Subcloning efficiency = } \\
\text { \# t established coll lines } \\
\text {; \# of cell lines tested (\%) }\end{array}$} & \multirow{2}{*}{$\begin{array}{l}\text { Anchorage-independent } \\
\text { cells / cell lines lested } \\
(\%)\end{array}$} \\
\hline & Exp. 1 & Exp. 2 & Exp. 3 & Exp. 4 & & \\
\hline c-myc + ras & 288 & 304 & 310 & 325 & $13 / 16(81 \%)$ & $12 / 14(86 \%)$ \\
\hline$c-m y c+r a s+L-m y c$ & 170 & 200 & 165 & 163 & $8 / 16(50 \%)$ & $9 / 14(64 \%)$ \\
\hline $\mathrm{N}-\mathrm{myc}+$ ras & 150 & 141 & 155 & 140 & $11 / 16(69 \%)$ & ND \\
\hline $\mathrm{N}-\mathrm{myc}+\mathrm{ras}+\mathrm{L}-\mathrm{myc}$ & 112 & 115 & 111 & 107 & $7 / 16(44 \%)$ & ND \\
\hline L-myc + ras & 12 & 20 & 16 & 18 & $0 / 10(0 \%)$ & ND \\
\hline
\end{tabular}

Figure 2. Transformation of REFs with c-myc or $\mathrm{N}-m y c /$ ras with or without zip constructs and with or without L-myc. $(A)$ Each plate of REFs was transfected with 2 $\mu \mathrm{g}$ of c-myc and $2 \mu \mathrm{g}$ of ras with or without $2 \mu \mathrm{g}$ of the zip constructs, as indicated in the transfected DNA column, and the total number of foci on 12 plates derived from 4 transfected plates was counted 11 days after transfection in two separate experiments. Foci were harvested and established as permanent cell lines with the indicated subcloning efficiency and assayed for anchorage-independent growth as described in Materials and methods. $(B)$ Same as in $A$, except REFs were transfected with $\mathrm{N}$-myc/ras with or without the zip constructs. $(C)$ Same as in $A$, except REFs were transfected with $10 \mu \mathrm{g}$ of $E 1 a$ and $2 \mu \mathrm{g}$ of ras with or without the zip constructs, and foci were counted 7 days after transfection in two separate experiments. (ND) Not determined. $(D)$ Same as in $A$, except REFs were transfected with c-myc/ras or $\mathrm{N}-m y c /$ ras with or without $\mathrm{L}$-myc or with L-myc/ras alone. same Northern blot was successively stripped and assayed for expression of the shorter zip transcripts, most of the permanently established zip-transfected cell lines were found to express lower levels of the zip-encoded transcripts relative to those produced by the transfected myc expression construct (Fig. 3B, N-myc panel, lanes 25-32; L-myc panel, lanes 16-24). In addition, despite linearization of the zip constructs, significant variability in the zip-encoded transcript sizes was observed. Because REFs do not express the endogenous $\mathrm{N}-m y c$ and L-myc genes, the variable pattern of zip-encoded transcripts was more readily discerned in the c-myc $+\mathrm{N}$-zip and c-myc + L-zip samples (Fig. 3B, N-myc panel, lanes 2532; L-myc panel, lanes 16-24). In addition, cell lines that expressed zip transcripts of proper size were found to express somewhat higher levels of the wild-type c-myc mRNA relative to cell lines with aberrant zip transcript forms (e.g., Fig. 3B, N-myc panel, lanes 25, 26, and 28 contain proper size zip transcripts). Finally, expression of the endogenous rat $\max$ gene was found to be similar in all REF transformants assayed (Fig. 3B, myn panel, lanes 16-32; similar results were obtained for samples 1-15; data not shown). Together, these results were consistent with the existence of strong selective forces operating against the high-level expression of normal c-zip, N-zip, or L-zip transcripts.

Comparable expression of introduced myc and zip genes in transiently transfected REFs Selection against zip gene expression was supported further by a series of transient transfection assays that were designed to compare the efficiency of zip versus myc construct expression before selection at the level of transformation. In these experiments early-passage REF monolayers were trans- 
A
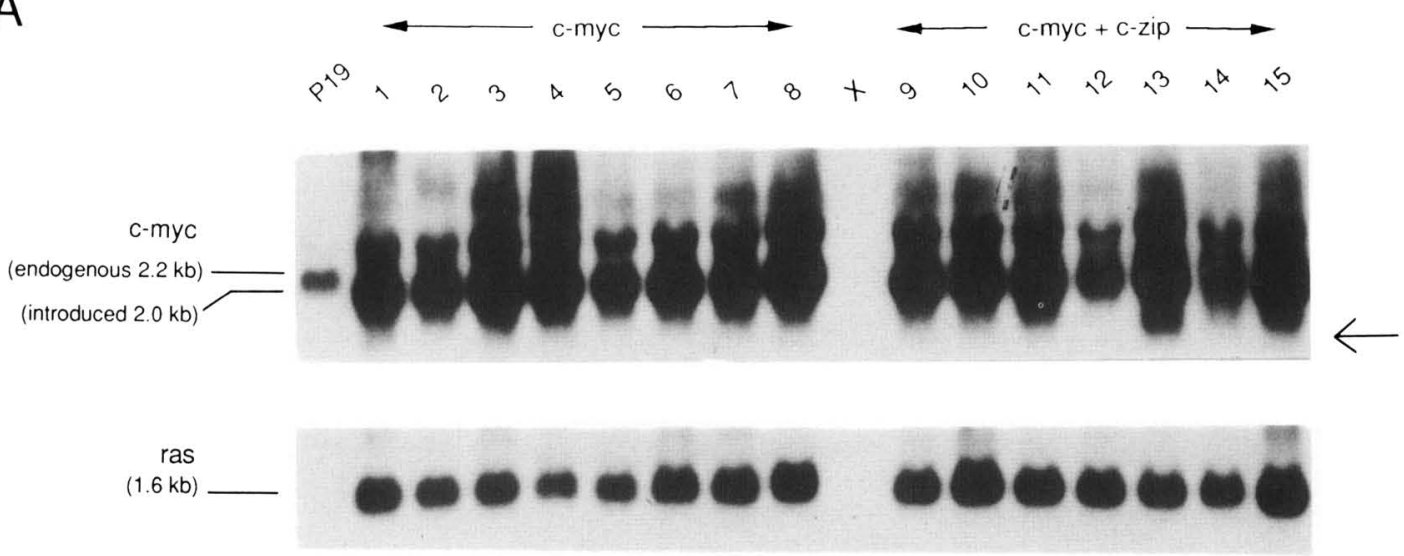

GAPDH

$(1.8 \mathrm{~kb})$
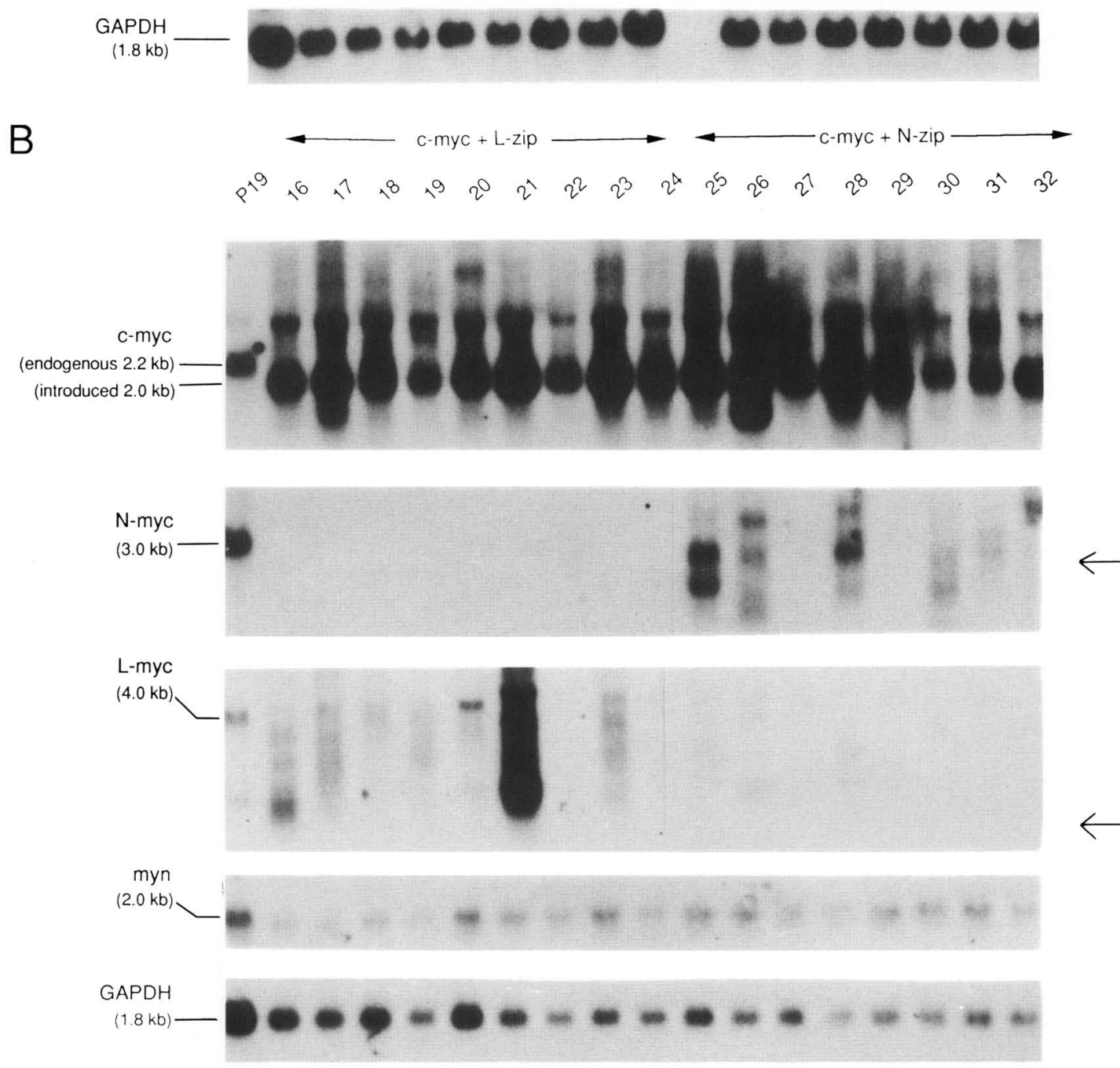

Figure 3. Northern analysis of stably transformed REF cell lines. $(A)$ Twenty micrograms of total RNAs derived from P19 cells, from a panel of several c-myc/ras-transfected REF-transformed cell lines (lanes 1-8), and from a panel of several c-myc/ras/c-zip-transfected REF-transformed cell lines was probed with radiolabeled fragments specific to probes indicated at left. For the myc hybridizations, the same Northern blot was successively dehybridized and hybridized with radiolabeled probes of similar specific activities, followed by exposures for similar lengths of time. The transcript size is shown below each gene for both endogenous and introduced genes. The arrows indicate the positions where the zip transcript is expected to run. $\{B\}$ Same as in $A$, except total RNAs derived from several c-myc/ras/L-zip (lanes 16-24) and c-myc/ras/N-zip (lanes 25-32) cell lines were assayed. 
fected with equimolar amounts of the various myc and zip expression constructs. Total RNAs were isolated 48 $\mathrm{hr}$ after transfection and assayed for expression of the introduced constructs. In contrast to the stably transfected REF cell lines described above, each transiently transfected zip expression construct generated steadystate mRNA levels that were comparable to levels produced by their respective myc expression constructs. Moreover, each zip construct was found to encode a single prominent transcript species of expected size rather than the irregular transcript forms detected in stably transfected lines. For example, in the $\mathrm{N}$-zip and $\mathrm{N}$-myc cotransfections, the $\mathrm{N}$-zip construct generated a distinct 2.4-kb transcript (Fig. 4, N-zip lanes) and yielded levels of expression that were comparable to levels of the $2.5 \mathrm{~kb}$ transcript encoded by the $\mathrm{N}$-myc construct (Fig. 4, $\mathrm{N}-m y c$ lanes). Similar results were obtained for c-zip and L-zip expression constructs (data not shown). Transfection efficiencies were found to be similar for each transfection point, as determined by expression levels of a cotransfected human growth hormone gene /data not shown). Overall, the comparable levels of expression and the production of a distinct transcript for all constructs clearly indicate that selection against zip gene expression takes place at the level of cellular transformation in the stably transfected lines.

Intracellular L-Myc/Max heterodimers exist in L-myc/ ras transformants The results of the previous experiments demonstrated that L-myc and various zip expression constructs can diminish c-myc and N-myc cotransformation activity. This effect may occur through competition for Max or common gene targets, or both. Although heterodimer complex formation between Max and all three Myc proteins has been shown to occur in vitro (Blackwood and Eisenman 1991), intracellular Myc/Max heterodimers have thus far been substantiated only for c-Myc (Blackwood et al. 1992; Kato et al. 1992) and N-Myc (Wenzel et al. 1991) proteins.

We attempted to document similar intracellular interactions between L-Myc and Max to determine whether L-Myc/Max interactions do represent a possible mechanism by which L-Myc or Zip can function as trans-dom- inant repressors. c-myc/ras- and L-myc/ras-transformed REFs were depleted of intracellular methionine and subsequently metabolically labeled with radioactive $\left.{ }^{35} \mathrm{~S}\right]$ methionine. Cell lysates were precipitated under high-stringency conditions with an anti-Max antibody to confirm that REFs expressed Max protein (Fig. 5A, lane a). A 21- to 22-kD band, detected in all REF lines, was verified to be Max protein as it disappeared specifically when an unlabeled glutathione $S$-transferase (GST)-Max fusion protein was included in the immunoprecipitation (Fig. 5A, lane b). The same antibody was used in immunoprecipitations under low-stringency conditions that permitted Max-associated proteins to remain complexed with Max and be coimmunoprecipitated (Fig. 5A, lanes $\mathrm{c}-\mathrm{f})$. The immunoprecipitated fractions from the c-myc/ ras and L-myc/ras transformants appeared to possess unique bands in the size range of $62-64$ and $66-68 \mathrm{kD}$, respectively, which were not detected in nontransformed REFs, or myc/ras-transformed REFs when the anti-Max antibody was blocked in the immunoprecipitation (Fig. 5A, lanes d, e, c, and f, respectively). To confirm that these were the c-Myc and L-Myc proteins, proteins immunoprecipitated under low-stringency conditions with anti-Max antisera were dissociated and reimmunoprecipitated under high-stringency conditions with an anti-human-c-Myc antibody that cross-reacts with all members of the Myc family (Fig. 5A, lanes h,i). Because the immunoprecipitated bands migrated at mobilities observed previously for Myc family proteins and were not readily detected in the nontransformed REF control or when preimmune serum was used (Fig. 5A, lanes g, il, we conclude that these are the c-Myc and L-Myc proteins. Similar results were obtained with $\mathrm{N}-\mathrm{Myc}$ and Max in the N-myc/ras transformants /Fig. $5 \mathrm{~B}$, lanes $\mathrm{k}-\mathrm{p}$ ). These data confirm that $\mathrm{c}-\mathrm{Myc} /$ Max and $\mathrm{N}-\mathrm{Myc} /$ Max heterodimers do form intracellularly and, for the first time, demonstrate that L-Myc and Max associate in vivo.

\section{Elevated levels of myn can profoundly inhibit the transforming activity of all three myc family genes}

A close biochemical relationship between Myc and Max has been established at the level of direct protein inter-

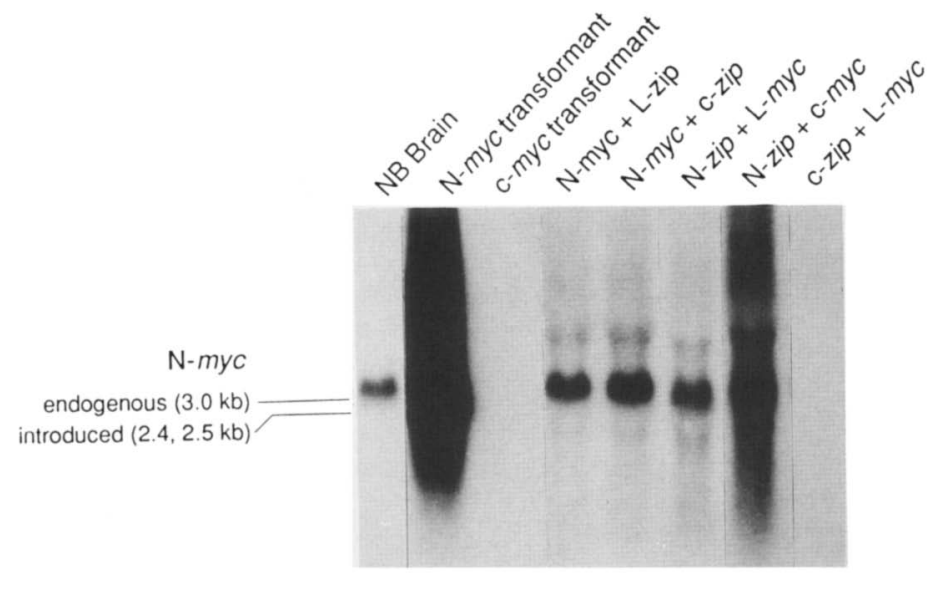

Figure 4. Northern analysis of transiently transfected REF cells. Twenty micrograms of total RNAs derived from REF monolayers transiently transfected with the indicated expression constructs was probed with a radiolabeled probe specific for mouse $\mathrm{N}-m y c$. The transcript sizes for the endogenous $(3.0 \mathrm{~kb})$, introduced $(2.5 \mathrm{~kb})$, and mutant $(2.4 \mathrm{~kb})$ $\mathrm{N}-m y c$ genes are indicated. Newborn brain RNA serves as a control for the endogenous levels of myc normally expressed in a developing tissue. N-myc and c-myc transformants are stably transfected REF cell lines. 


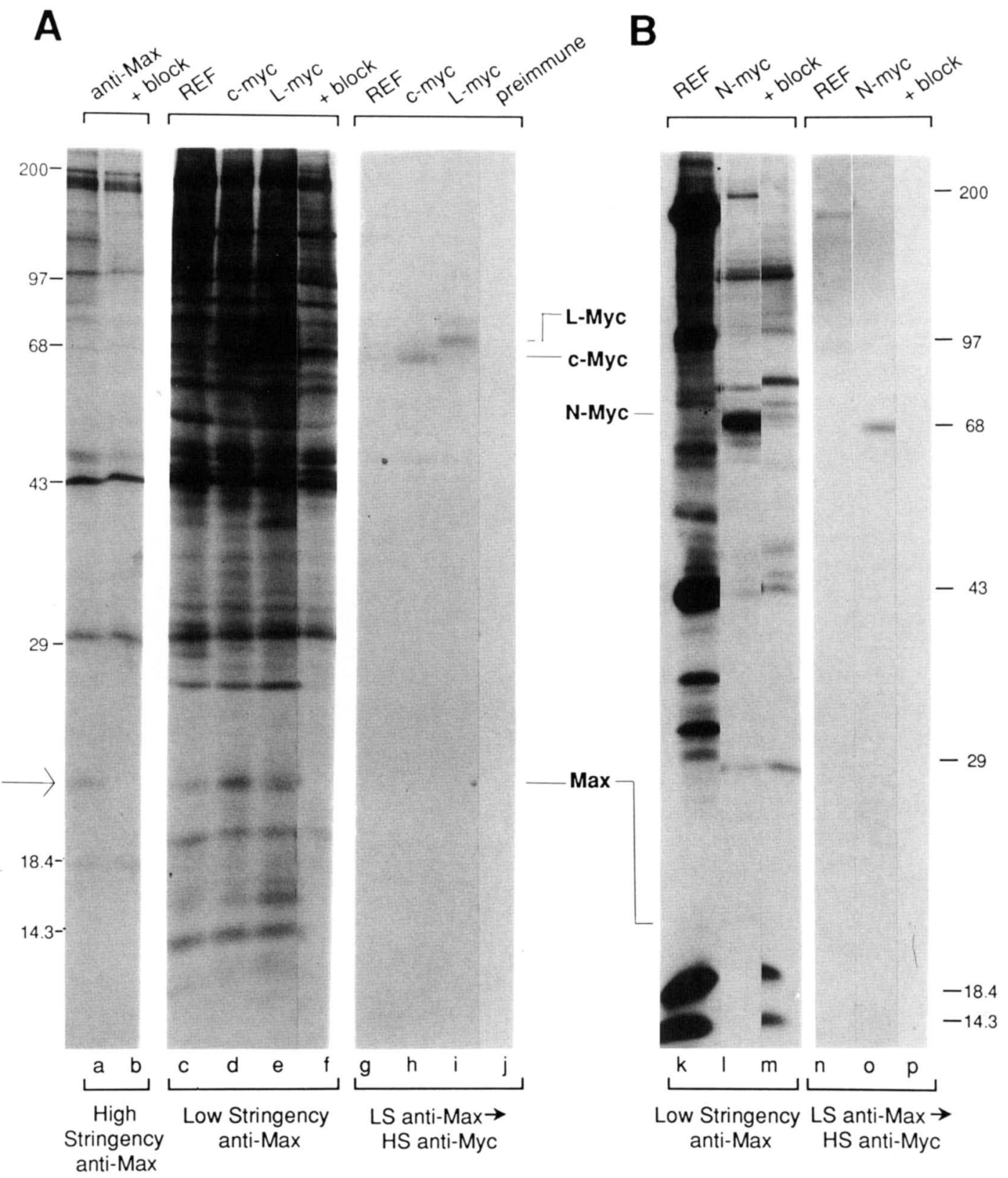

Figure 5. Identification of Myc-Max complexes in myc/ras-transformed REF cell lines. (A) Identification of c-Myc/Max and L-Myc/ Max complexes. $\left[{ }^{35} \mathrm{~S}\right]$ Methionine-labeled cell lysates were immunoprecipitated under high-stringency conditions with an anti-human Max antibody to identify the Max protein, which is indicated. The blocked sample included an excess of cognate immunogen to block specific immunoprecipitation (lane $b$ ), whereas the anti-Max lane represents an unblocked sample (lane a). To identify Max and Max-associated proteins, $\left.{ }^{35} \mathrm{~S}\right]$ methionine-labeled cell lysates from the indicated samples were immunoprecipitated with an anti-Max antibody under low-stringency conditions that preserve Max and associated protein interactions (lanes $c-f$ ). Lanes $d$ and $e$ are immunoprecipitated protein from c-Myc- and L-Myc-transformed REFs, respectively; lane $f$ represents one sample in which anti-Max was blocked. Nontransfected REFs express low levels of the endogenous c-Myc protein (lane $c$ ). The samples in lanes $c-e$ were dissociated with ionic detergents and reprecipitated under high-stringency (HS) conditions with an anti-Myc antibody to verify the presence of Myc proteins in the Max-associated protein pool (lanes g-i). The preimmune sample was immunoprecipitated with the preimmune serum instead of the anti-Myc antibody (lane $i$ ). Sizes of molecular weight markers are indicated at left. The positions of Max and Myc proteins are indicated. $(B)$ Identification of $\mathrm{N}-\mathrm{Myc} / \mathrm{Max}$ complexes. (Lanes $k-m$ ) Same as in $A$, lanes $c-f$, except low-stringency anti-Max immunoprecipitation was carried out with a N-Myc-transformed REF cell line without or with blocking the antibody (lanes $l, m)$. (Lanes $n-p$ ) Same as in $A$, lanes $g-i$, except subsequent high-stringency immunoprecipitation with the anti-Myc antibody was carried out with samples in $k-m$. 
action and common sequence recognition specificity for Myc/Max and Max/Max complexes. Mutations in the HLH domain of c-Myc that inhibit dimerization with Max have been shown to eliminate c-Myc biological activities, including transformation, inhibition of differentiation, and autoregulation (for review, see Lüscher and Eisenman 1990; Penn et al. 1990). To better understand the biological role of Max with respect to c-Myc, N-Myc, and L-Myc cotransformation activity in vivo, an expression construct encoding the mouse Max protein was tested for its ability to influence the transforming activity of mouse c-Myc, N-Myc, or L-Myc in the REF cooperation assay. For each point, c-myc, N-myc, or L-myc and the activated $\mathrm{H}$-ras expression constructs were cotransfected into early-passage REF alone or along with the max expression construct. As shown in Figure 6A, the addition of a 5 molar excess of max relative to myc was associated with a striking reduction in the number of foci produced for all three myc family genes. The maxinduced suppression resulted in an overall reduction of $95 \%$ in c-myc/ras-generated foci, $94 \%$ for $\mathrm{N}-\mathrm{myc} / \mathrm{ras}$, and $95 \%$ for L-myc/ras (Fig. 6B). To determine whether the relative molar ratio of transfected myc and max was an important parameter, a fixed amount of myc and ras was cotransfected along with an increasing molar amount of $\max$, ranging from a 0 to 5 molar ratio. An increase in the amount of added max was found to correlate closely with a progressive reduction in the number of foci generated (Fig. 6C). The reduction appeared to be linear over the range examined (Fig. 6D).

\section{Discussion}

\section{Cross-interference among the Myc family}

In this study we demonstrated that the three Myc mutants (termed c-Zip, N-Zip, and L-Zip), all lacking their putative trans-activation domain, significantly impaired the cotransformation activities of wild-type c-Myc and $\mathrm{N}-\mathrm{Myc}$, indicating that c-Myc, N-Myc, and L-Myc oncoproteins utilize common genetic elements for neoplastic transformation. As shown schematically in Figure 7A, coexpression of c-Zip, N-Zip, or L-Zip and Myc family proteins presumably leads to a competition for these genetic elements through the formation of $\mathrm{Zip} / \mathrm{Max}$ complexes, resulting in a titration of Max away from Myc and/or an occupation of Myc/Max-binding sites by the nonfunctional Zip/Max complex. The identical neutral-
A

\begin{tabular}{|l|r|r|}
\hline \multirow{2}{*}{ Transfected DNA } & \multicolumn{2}{|c|}{ Total \# of Foci } \\
\cline { 2 - 3 } & Exp. 1 & Exp. 2 \\
\hline C-myc + ras & 200 & 180 \\
C-myc + ras + max & 10 & 9 \\
N-myc + ras & 50 & 45 \\
N-myc + ras + max & 3 & 2 \\
L-myc + ras & 20 & 18 \\
L-myc + ras + max & 1 & 0 \\
\hline
\end{tabular}

C

\begin{tabular}{|c|c|}
\hline $\begin{array}{c}{[\mathrm{max}] /} \\
{[\mathrm{c}-\mathrm{myc}]}\end{array}$ & $\begin{array}{c}\text { Total \# } \\
\text { of Foci }\end{array}$ \\
\hline 0.00 & 200 \\
0.25 & 98 \\
1.00 & 54 \\
2.00 & 26 \\
5.00 & 9 \\
\hline
\end{tabular}

D
B
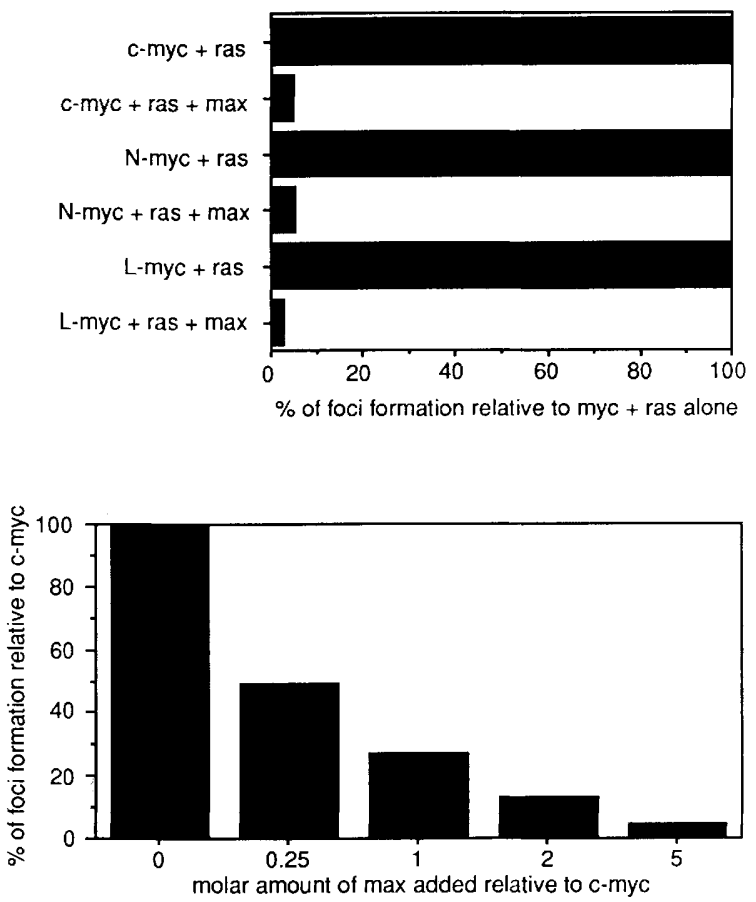

Figure 6. Transformation of REFs with c-myc/ras, N-myc/ras, or L-myc/ras with or without max. (A) See legend to Fig. 2, except that REFs were transfected with $c-m y c, N-m y c$, or L-myc with or without max and foci were counted 9 days after transfection. $(B)$ Relative foci formation numbers from samples in $A$ were derived by averaging the two experiments and expressing the total number of foci counted in each transfection that included the max expression construct as a percentage of the number of foci counted in the corresponding myc transfection, that excluded the max expression construct, which were each taken to be $100 \%$. $(C)$ Each plate of REFs was transfected with $2 \mu \mathrm{g}$ of c-myc, $2 \mu \mathrm{g}$ of ras, and the indicated molar amount of max DNA relative to c-myc, as indicated in the left column. The total number of foci from 12 plates derived from 4 transfected plates was counted 10 days after transfection. $(D)$ Relative foci formation numbers of samples in $A$ were derived by expressing the total number of foci counted in the max transfections as a percentage of the total number of foci counted with c-myc/ras only transfection, which is taken to be $100 \%$. 


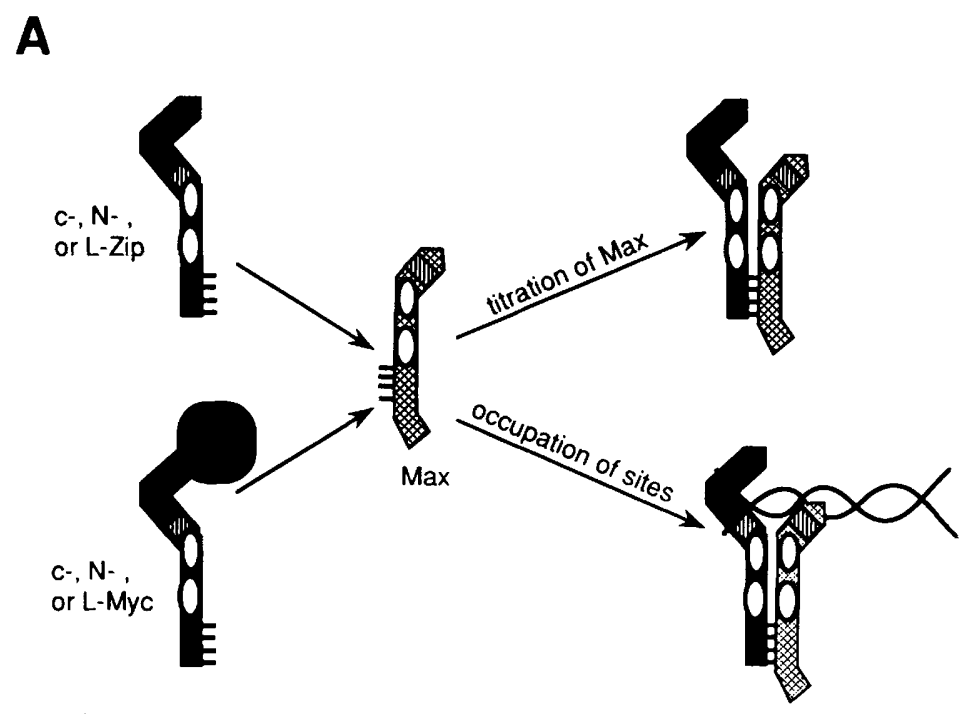

Figure 7. Proposed models of Zip and Max inhibition of Myc-transforming activity. (A) Zip-induced inhibition of Myc activity may occur through (1) titration of the Max pool by formation of Zip/Max heterodimers, thereby decreasing the formation of $\mathrm{Myc} / \mathrm{Max}$ heterodimers, and/or (2) occupation of target sequences by trans-activation-incompetent Zip/Max complexes. $(B)$ Alteration in the expression of Myc and Max can influence the formation of active vs. inactive complexes. High-level expression of Max protein can lead to the formation of Max homodimers, which may compete with Myc/Max heterodimers for binding a common gene target.

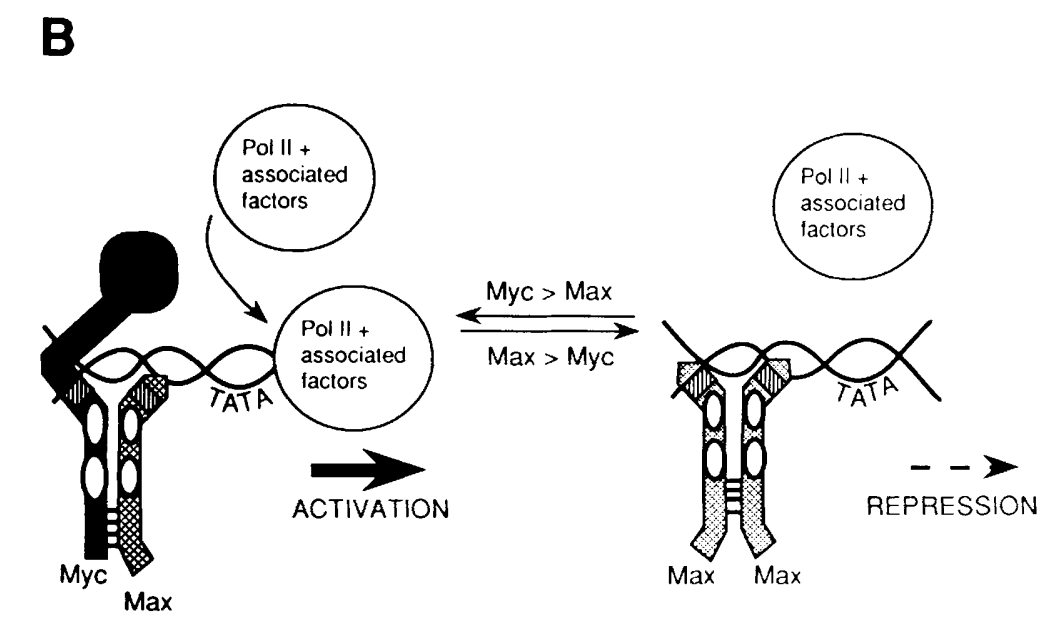

izing activity of each zip construct indicates that domains contained within the three Zip proteins are similar, if not identical, in function. These domains include those involved in nuclear localization, nonspecific and sequence-specific DNA binding, and protein oligomerization, all of which may allow for interaction with common genetic elements. We have provided evidence that the L-Myc protein is associated with the endogenous Max protein intracellularly in L-myc/ras REF transformants. These observations, taken together with the documented intracellular associations of Max with c-Myc (Blackwood et al. 1992; Kato et al. 1992) and N-Myc proteins (Wenzel et al. 1991), support the hypothesis that interaction with Max represents at least one component common to Myc family function. Although the formation of Zip/Max heterodimers has not been documented in this study, several recent studies have demonstrated clearly that deletions or substitutions in the amino-terminal end of Myc proteins do not affect the dimerization or sequence-specific binding activities of the Myc protein (Blackwood and Eisenman 1991; Berberich and Cole 19921 .
The finding that c-Zip, N-Zip, and L-Zip proteins are functionally similar suggests that the differences in oncogenic potential among the Myc family are governed by biological properties encoded within the deleted aminoterminal region and are not the result of factors such as differential affinities for the Max protein or target sequences, among other possibilities. The amino-terminal sequences, deleted in the c-Myc mutant, have been shown to encode trans-activation potential (Kato et al. 1990) and appear to be indespensible for cotransformation activity (Stone et al. 1987). Deletion of the equivalent region in N-Myc and L-Myc also rendered them oncogenically inactive. These functional data, coupled with the high degree of amino acid sequence conservation, suggest that the amino-terminal region of N-Myc and L-Myc may also encode trans-activation potential. If this is the case, it would be of interest to measure the trans-activation potential for each Myc family member and correlate this with oncogenic potency. One would anticipate that the potent c-Myc oncoprotein would possess a superior ability, relative to N-Myc and L-Myc, in trans-activating the expression of growth-promoting 
gene targets involved in cellular transformation. Support for such a concept awaits clear evidence of transcriptional regulation of specific growth-related genes by the Myc family. Nevertheless, this notion compares with that established experimentally for the structurally (Ralston and Bishop 1983) and functionally (Ralston 1991) related E1A viral oncoproteins, of which the 13S E1A oncoprotein has been shown to be both a potent activator of early viral transcription and a strong transforming agent, and the weakly transforming $12 \mathrm{~S}$ form possesses minimal trans-activation potential.

The dominant interference approach also provided some insight into the relationship between Ela and Myc family function in cellular transformation. The finding that Ela cotransformation activities were for the most part unaffected by dominant-negative mutants of the Myc family clearly indicates that unimpaired Myc function in not an essential requirement for Ela cotransformation activities. This suggests that Ela may function to transform cells through pathways that are independent or downstream of Myc-related activities.

\section{Physiological consequences of coordinate Myc family expression}

We also sought to better understand the physiological significance of the relatively weak biological activity of the L-Myc protein in relation to that of $\mathrm{c}-\mathrm{Myc}$ and $\mathrm{N}$-Myc. We confirmed that the mouse L-Myc protein was capable of transforming REFs to a limited extent and have demonstrated that this reduced activity is not the result of an inability to interact with Max. We studied the physiological effect of L-Myc on c-Myc or N-Myc in the same cell by transforming REFs with $c-m y c$ or $\mathrm{N}$-myc plus ras with or without L-myc. L-Myc clearly diminished the transforming potential of $\mathrm{c}-\mathrm{Myc}$ and $\mathrm{N}-\mathrm{Myc}$ to a level intermediate of that of $\mathrm{c}-\mathrm{Myc}$ or N-Myc and L-Myc by themselves. We speculate that this effect results from the titration of Max into a complex of weak transforming ability (L-Myc/Max), which may impact on the oncogenic potency of c-Myc and N-Myc by reducing the chances of forming active c-Myc/Max and N-Myc/ Max heterodimers. Alternatively, if Max is not limiting in the cell, the competition for and occupation of a common target sequence in growth control genes by the L-Myc/Max complex may decrease accessibility for c-Myc/Max or N-Myc/Max complexes and consequently reduce the overall level of activation of these common gene targets.

The theory that a normal function of L-Myc may be to regulate the formation of $\mathrm{c}-\mathrm{Myc} / \mathrm{Max}$ complexes or their access to target sequences and thereby modulate $\mathrm{c}-\mathrm{Myc}$ activity is of particular significance given the observation that L-myc can be expressed coordinately with c-myc and $\mathrm{N}-\mathrm{myc}$ in many normal developing cells $\langle\mathrm{Mu}-$ grauer and Ekblom 1991; K.A. Mahon and R.A. DePinho, unpubl.) Support for this concept derives from recent experiments in transgenic mice showing that forced cell type-specific expression of L-myc, N-zip, or L-zip constructs in differentiating lens fiber cells, which normally express $\mathrm{N}-\mathrm{myc}$ only, may have induced a phenotype in which expression of specific late-stage differentiation markers has been delayed (S.D. Morgenbesser, B. Mukherjee, and R.A. DePinho, unpubl.). As such, the activity of N-Myc in these cells may have been reduced owing to titration of Max and/or occupation of common gene targets by the introduced L-Myc or Zip proteins.

\section{Role of Max in the regulation of Myc activity}

We were also interested in studying the biological impact of Max on the cotransformation activity of each Myc family member. We demonstrated that addition of a mouse max expression construct to the myc/ras cotransfections resulted in a striking decrease in the cotransformation activity of all three Myc family proteins. Suppression was found to be linear over a wide range of $\max$ concentrations. Our biological results are consistent with several recently described biochemical features of the Max protein, and a model depicting Max regulation of Myc activity is presented in Figure 7B. Most notably, Max can form homodimeric complexes that appear to lack trans-activation potential but have the capacity to bind the same hexameric sequence (CACGTG) recognized by the Myc/Max heterodimeric complex. Together, these findings are consistent with a model proposed previously (Kato et al. 1992), which states that because Max homodimers occupy the CACGTG sequence as transcriptionally inert complexes, they may deny access by the Myc/Max trans-activation complex, thus implicating a role for Max homodimers as negative regulators of Myc activity. It has been theorized that when Myc protein levels are limiting in vivo, Max homodimers form and bind in a repressive fashion to genes whose promoters/enhancers bear the CACGTG motif. With the induction of high-level Myc expression during active cellular proliferation, the balance would be shifted toward the formation of $\mathrm{Myc} / \mathrm{Max}$ heterodimers. On the basis of this model, suppression of Myc cotransformation ability by Max in our experiments could have resulted from the preferential formation of trans-activation-incompetent Max homodimers over trans-activation-competent Myc/Max heterodimers. Our results clearly support the current view of Myc/Max activity (for review, see Torres et al. 1992) and are in contrast to previous studies in which addition of the same max expression construct caused a moderate enhancement in c-Myc cotransformation activity, even with high max/ myc molar ratios (Prendergast et al. 1991). Although the basis for this difference is not clear, it is possible that differences in myc construct design may have achieved a more favorable intracellular ratio of $\mathrm{Myc} / \mathrm{Max}$ in the previous study, resulting in an overall increase in $\mathrm{Myc} / \mathrm{Max}$ heterodimers rather than Max homodimers.

Our studies have demonstrated that dominant interference represents a potentially useful strategy for elucidation of the role of myc family genes in normal physiology and malignant transformation. Although the effective use of this biological approach will require a more complete understanding of the range of potential dimer- 
ization specificities of the Myc protein, dominant-negative mutants provide a means of abrogating Myc activity in a number of experimental systems. For instance, the targeting of dominant mutant proteins to specific cell lineages may prove useful in assessing myc family function during normal cell growth and differentiation. Similarly, we would anticipate that the conditional overexpression of Max would yield similar insights. An important and obvious application of this genetic approach would be the use of Zip or Max expression vectors as a therapeutic modality in malignant disease.

\section{Materials and methods}

myc and zip expression vectors and their construction

The various myc and ras plasmids used in the REF transfections are as follows: pT24-ras contains the mutant $\mathrm{H}$-ras oncogene (val12) (Fasano et al. 1983); pKO-myc is a c-myc expression construct in which transcription of the second and third exons of the mouse c-myc gene is driven from an SV40 promoter; pRN2,3 is an N-myc expression construct in which transcription of the second and third exons of the mouse $\mathrm{N}$-myc gene is driven from the RSV/LTR; and pRL2,3 is an L-myc expression construct in which transcription of the second and third exons of the mouse L-myc gene is driven from the RSV/LTR.

The various zip constructs are as follows: c-zip encodes a mutant c-myc gene derived from the mouse c-myc cDNA, graciously provided by Dr. Ken Marcu (pMc-myc54; Stanton et al. 1983); the Xhol fragment utilized contains a 414-bp in-frame deletion that removes amino acids $40-178$; transcription of c-zip is driven from the RSV/LTR, and the coding domain is followed by an 847-bp BgIII-BamHI fragment encoding the SV40 splice and polyadenylation signal (Gorman et al. 1982). $\mathrm{N}$-zip consists of an $\mathrm{N}-m y c$ genomic fragment containing the second and third coding regions (DePinho et al. 1986) with a deletion that removed amino acid residues $18-128$; the open reading frame was maintained in-frame by a bridging oligomer. L-zip encodes a mutant L-Myc protein with a deletion of amino acid residues 23-140. This construct was derived from the mouse L-myc cDNA (Legouy et al. 1987). Both N-zip and L-zip are driven by the RSV/LTR and contain the SV40 polyadenylation signal described in c-zip. All zip expression constructs are illustrated in Figure 1. CMVmyn, a max expression construct, kindly provided by Ed Ziff (New York University), consists of a full-length cDNA encoding the complete mouse max gene driven by the cytomegalovirus (CMV) promoter/enhancer; this construct was described previously (Prendergast et al. 1991). plA encodes the E1A viral oncoprotein described previously (Prendergast et al. 1991).

\section{Analysis of RNA and DNA}

DNA preparation, restriction endonuclease digestions, probe preparation by the nick-translation method, blotting procedures, and hybridization conditions were performed as described previously (DePinho et al. 1986). Total RNA was isolated by the $\mathrm{LiCl} /$ urea method as described previously (Auffray and Rougeon 1980) from P19 embryonal carcinoma cells (McBurney et al. 1982), from mouse newborn brain or from exponentially growing cultures of the various transformed REF cell lines. Twenty micrograms of total RNA was fractionated by electrophoresis on a $1 \%$ agarose/formaldehyde gel, transferred to nitrocellulose, and hybridized as described (Xu et al. 1991). RNAs were judged to be intact and evenly loaded by ethidium staining, as well as by hybridization to the rat glyceraldehyde3-phosphate dehydrogenase (GAPDH) gene (Tso et al. 1985). myc-specific probes included (1) c-myc, a 780-bp PstI-XhoI fragment consisting of the coding domain derived from the c-myc cDNA plasmid pMc-myc54 (Stanton et al. 1983; a generous gift from K. Marcu); (2) L-myc, a 480-bp BamHI-HindIII fragment containing the third exon derived from the genomic clone $\mathrm{B} 1$ (Legouy et al. 1987); and (3) N-myc, a 635-bp Clal-HincII fragment containing the coding portion of third exon derived from the genomic clone pN7.7 (DePinho et al. 1986). To ascertain the relative levels of myc versus zip gene expression, Northern blots were hybridized with probes of similar specific activities and exposed for the same length of time. In this manner, the various Northern blot hybridizations were found to yield comparable levels of steady-state myc family gene expression in the P19 control sample in all experiments.

\section{Preparation and transfection of REFs}

Early-passage cultures of REFs were prepared as described elsewhere (Yancopoulos et al. 1985) from 12- to 14-day Fischer rat embryos. Freshly harvested REFs were initially plated at nearconfluent density, allowed to grow to confluency, expanded $1: 5$, and frozen on reaching confluency. To prepare for transfection, REFs were thawed and replated at $1 \times 10^{6} \mathrm{cells} / 10-\mathrm{cm}$ plate in Dulbecco's modified Eagle (DME) medium supplemented with $10 \%$ fetal bovine serum (FBS). DNAs were introduced into REFs by the calcium phosphate precipitation method as described previously (Andersson et al. 1979) by use of $30 \mu \mathrm{g}$ of mouse liver carrier DNA with $2 \mu \mathrm{g}$ of each of the appropriate plasmid DNAs per plate, except for $10 \mu \mathrm{g}$ in the case of CMVmyn (mouse max expression construct). For the max dose response experiments, each plate received $2 \mu \mathrm{g}$ of the myc and $\mathrm{H}$-ras plasmids along with the indicated amount of CMVmyn $(0.5,2,4$, or $10 \mu \mathrm{g})$. In the Ela cotransformations, $10 \mu \mathrm{g}$ of plA was used. The cultures were refed $6-9 \mathrm{hr}$ after transfection and split $1: 3, \sim 20 \mathrm{hr}$ after the transfection. Foci were counted 9-12 days after transfection. The transient transfection was performed in the same manner as described above, except that 25 $\mu \mathrm{g}$ instead of $2 \mu \mathrm{g}$ of the indicated plasmids was added per plate and no genomic DNA carrier was used. At $48 \mathrm{hr}$, the transiently transfected plates were harvested for total RNA. Controls for cotransfection efficiency included a human growth hormone gene that demonstrated comparable expression levels in all stably and transiently transfected cells (data not shown).

\section{Assay for colony formation in soft agar}

A single cell suspension of $\sim 1 \times 10^{4}$ cells in $5 \mathrm{ml}$ of $0.28 \%$ agar was overlaid onto a $60-\mathrm{mm}$ culture dish containing a $0.7 \%$ agar base. All agar suspensions were made in DME media supplemented with $10 \%$ FBS. Duplicate plates were prepared for each line tested.

\section{Immunoprecipitation}

The polyclonal rabbit antisera against human c-myc and human max have been characterized previously (Blackwood and Eisenman 1991). Metabolic labeling of REF cells and immunoprecipitation under low-stringency conditions to recover Myc/Max heterodimers and high-stringency conditions to recover uncomplexed proteins was essentially as described (Blackwood et al. 1992). All samples were analyzed by SDS-PAGE on $15 \%$ polyacrylamide gels under reducing conditions and exposed to autoradiography. 


\section{Acknowledgments}

We are indebted to Beth Blackwood and Bob Eisenman for their assistance, generosity, and advice on the coimmunoprecipitation studies. We thank Art Skoultchi, Shimon Efrat, Scott Mellis, and Nicole Schreiber-Agus for critical reading of this manuscript. We also thank Jolaine Lauridsen for secretarial assistance and Joseph DePinho for graphic art work. S.D.M. is supported by National Institutes of Health (NIH) training grant CA09173-14. R.A.D. is supported by NIH grants ROl EY09300-01 and ROl HD28317-01, a McDonnell Foundation Scholar Award, a Cancer Research Institute Investigator Award, and an American Heart Association Investigator Award. R.A.D. and B.M. (aka B. Mukhopadhyay) are aided by the Basil O'Connor Starter Scholar Research Award (5-724) through funds received from the Lifespring Foundation to the March of Dimes Defects Foundation. This work was also supported by the Cancer Center Core NIH grant 2P30CA13330-20.

The publication costs of this article were defrayed in part by payment of page charges. This article must therefore be hereby marked "advertisement" in accordance with 18 USC section 1734 solely to indicate this fact.

\section{References}

Andersson, P., M.P. Goldfarb, and R.A. Weinberg. 1979. A defined subgenic fragment of in vitro synthesized Moloney sarcoma virus DNA can induce cell transformation upon transfection. Cell 16: 63-75.

Auffray, C. and F. Rougeon. 1980. Purification of mouse immunoglobulin heavy chain messenger RNAs from total myeloma tumor RNA. Eur. J. Biol. 107: 303-314.

Berberich, S.J. and M.D. Cole. 1992. Casein kinase II inhibits the DNA-binding activity of Max homodimers but not Myc/ Max heterodimers. Genes \& Dev. 6: 166-176.

Birrer, M.J., S. Segal, J.S. DeGreve, F. Kaye, E.A. Sausville, and J.D. Minna. 1988. L-myc cooperates with ras to transform rat-embryo fibroblasts. Mol. Cell. Biol. 8: 2668-2673.

Blackwell, T.K., L. Kretzner, E.M. Blackwood, R.N. Eisenman, and $H$. Weintraub. 1990. Sequence specific DNA binding by the c-Myc protein. Science 250: 1149-1152.

Blackwood, E.M. and R.N. Eisenman. 1991. Max: A helix-loophelix zipper protein that forms a sequence-specific DNA binding complex with Myc. Science 251: 1211-1217.

Blackwood, E.M., B. Lüscher, and R.N. Eisenman. 1992. Myc and Max associate in vivo. Genes \& Dev. 6: 71-80.

Dang, C.V. and W.M.F. Lee. 1988. Identification of the human c-Myc protein nuclear translocation signal. Mol. Cell. Biol. 8: $4048-4054$.

Dang, C.V., M. McGuire, M. Buckmire, and W.M.F. Lee. 1989. Involvement of the leucine zipper region in the oligomerization and transforming activity of human c-Myc protein. $\mathrm{Na}$ ture 337: 664-666.

DePinho, R.A., E. Legouy, L.B. Feldman, N.E. Kohl, G.D. Yancopoulos, and F.W. Alt. 1986. Structure and expression of the murine N-myc gene. Proc. Natl. Acad. Sci. 83: 1827-1831.

DePinho, R.A., L. Mitsock, K. Hatton, P. Ferrier, K. Zimmerman, E. Legouy, A. Tesfaye, R. Collum, G. Yancopoulos, P. Nisen, R. Kriz, and F. Alt. 1987a. myc family of cellular oncogenes. J. Cell. Biochem. 33: 257-266.

DePinho, R.A., K.S. Hatton, A. Tesfaye, G.D. Yancopoulos, and F.W. Alt. 1987b. The human myc gene family: Structure and activity of L-myc and an L-myc pseudogene. Genes \& Dev. 1: 1311-1326.

DePinho, R.A., N. Schreiber-Agus, and F.W. Alt. 1991. myc family oncogenes in the development of normal and neoplastic cells. Adv. Cancer Res. 57: 1-45.

Fasano, O., E. Taparowsky, J. Fiddes, M. Wigler, and M. Goldfarb. 1983. Sequence and structure of the coding region of the human H-ras-1 gene for T24 bladder carcinoma cells. J. Mol. Appl. Genet. 2: 123-180.

Gorman, C.M., L.F. Moffat, and B.H. Howard. 1982. Recombinant genomes which express chloramphenicol acetyltransferase in mammalian cells. Mol. Cell. Biol. 2: 1044-1051.

Halazonetis, T.D. and A.N. Kandil. 1991. Determination of the c-Myc DNA-binding site. Proc. Natl. Acad. Sci. 88: 61626166.

Herskowitz, I. 1987. Functional inactivation of genes by dominant negative mutations. Nature 329: 219-222.

Kato, G.J., J. Barrett, M. Villa-Garcia, and C.V. Dang. 1990. An amino-terminal domain of $\mathrm{c}-\mathrm{Myc}$ required for transformation activates transcription. Mol. Cell. Biol. 10: 5914-5920.

Kato, G.J., W.M.F. Lee, L. Chen, and C.V. Dang. 1992. Max: Functional domains and interaction with c-Myc. Genes \& Dev. 6: 81-92.

Kerkhoff, E., K. Bister, and K.-H. Klempnauer. 1991. Sequencespecific DNA binding by Myc proteins. Proc. Natl. Acad. Sci. 88: 4323-4327.

Land, H., L.F. Parada, and R.A. Weinberg. 1983. Tumorigenic conversion of primary embryo fibroblasts requires at least two cooperating oncogenes. Nature 304: 596-601.

Landschulz, W.H., P.F. Johnson, and S.L. McKnight. 1988. The leucine zipper: A hypothetical structure common to a new class of DNA binding proteins. Science 240: 1759-1764.

Lassar, A.B., J.N. Buskin, D. Lockshon, R.L. Davis, S. Apone, S.D. Hauschka, and H. Weintraub. 1989. MyoD is a sequence specific DNA binding protein requiring a region of myc homology to bind to the muscle creatine kinase enhancer. Cell 58: 823-831.

Legouy, E., R. DePinho, K. Zimmerman, R. Collum, G. Yancopoulos, L. Mitsock, R. Kriz, and F.W. Alt. 1987. Structure and expression of the murine L-myc gene. EMBO J. 6: 33593366.

Lüscher, B. and R.N. Eisenman. 1990. New light on Myc and Myb. Part 1. Myc. Genes \& Dev. 4: 2025-2035.

McBurney, M.W., E.M.V. Jones-Villeneuve, M.R.S. Edwards, and P.T. Andersen. 1982. Control of muscle and neuronal differentiation in a cultured embryonal carcinoma cell line. Nature 299: 165-167.

Moroy, T., F.W. Alt. and R.A. DePinho. 1991. Use of transgenic mice to study normal and abnormal mammalian development. In Molecular foundation of oncology. Chapter 22, pp. 455-487. Williams and Wilkins, Baltimore, MD.

Mugrauer, G. and P. Ekblom. 1991. Contrasting expression patterns of three members of the myc family of protooncogenes in the developing and adult mouse kidney. I. Cell Biol. 112: 13-25.

Murre, C., P. Schonleber-McCaw, and D. Baltimore. 1989. A new DNA binding and dimerization motif in immunoglobulin enhancer binding, daughterless, MyoD and myc proteins. Cell 56: 777-783.

Nisen, P.D., K.A. Zimmerman, S.V. Cotter, F. Gilbert, and F.W. Alt. 1986. Enhanced expression of the N-myc gene in Wilm's tumors. Cancer Res. 46: 6217-6222.

Penn, L.J.Z., M.W. Brooks, E.M. Laufer, and H. Land. 1990. Negative autoregulation of c-myc transcription. EMBO $J$. 9: $1113-1121$.

Prendergast. G.C. and E.B. Ziff. 1991. Methylation-sensitive sequence-specific DNA binding by the c-Myc basic region. Science 251: 186-189.

Prendergast, G.C., D. Lawe, and E.B. Ziff. 1991. Association of Myn, the murine homolog of Max, with c-Myc stimulates 
methylation-sensitive DNA binding and Ras cotransformation. Cell 65: 395-407.

Ralston, R. 1991. Complementation of transforming domains in E1A/myc chimaeras. Nature 353: 866-868.

Ralston, R. and J.M. Bishop. 1983. The protein products of the $m y c$ and myb oncogenes and adenovirus ElA are structurally related. Nature 306: 803-806.

Schwab, M., H.E. Varmus, and J.M. Bishop. 1985. The human $\mathrm{N}$-myc gene contributes to neoplastic transformation of mammalian cells in culture. Nature 316: 160-162.

Smith, M.J., D.C. Charron-Prochownik, and E.V. Prochownik. 1990. The leucine zipper of c-Myc is required for full inhibition of erythroleukemia differentiation. Mol. Cell. Biol. 10: $5333-5339$.

Stanton, L.W., R. Watt, and K.B. Marcu. 1983. Translocation, breakage and truncated transcripts of c-myc oncogene in murine plasmacytomas. Nature 303: 401-406.

Stone, J., T. deLange, G. Ramsay, F. Jakobovits, J.M. Bishop, H. Varmus, and W. Lee. 1987. Definition of regions in human c-myc that are involved in transformation and nuclear localization. Mol. Cell. Biol. 7: 1697-1709.

Torres, R., N. Schreiber-Agus, S.D. Morgenbesser, and R.A. DePinho. 1992. Myc and Max: A putative transcription factor in search of a cellular target. Curr. Opin. Cell Biol. 4: 468474.

Tso, J.Y., X.-H. Sun, T.-H. Kao, K.S. Reece, and R. Wu. 1985. Isolation and characterization of rat and human glyceraldehyde-3-phosphate dehydrogenase cDNAs genomic complexity and molecular evolution of the gene. Nucleic Acids Res. 13: 2485-2502.

Wenzel, A., C. Cziepluch, U. Hamann, J. Schurmann, and M. Schwab. 1991. The N-Myc oncoprotein is associated in vivo with the phosphoprotein Max (p20/22) in human neuroblastoma cells. EMBO J. 10: 3703-3712.

Xu, L., S.D. Morgenbesser, and R.A. DePinho. 1991. Complex transcriptional regulation of myc family gene expression in the developing mouse brain and liver. Mol. Cell. Biol. 11: $6007-6015$.

Yancopoulos, G.D., P.D. Nisen, A. Tesfaye, N.E. Kohl, M.P. Goldfarb, and F.W. Alt. 1985. N-myc can cooperate with ras to transform normal cells in culture. Proc. Natl. Acad. Sci. 83: $5455-5459$.

Zimmerman, K.A., G.D. Yancopoulos, R.G. Collum, R.K. Smith, N.E. Kohl, K.A. Denis, M.M. Nau, O.N. Witte, D. Toran-Allerard, C.E. Gee, J.D. Minna, and F.W. Alt. 1986. Differential expression of myc family genes during murine development. Nature 319: 780-783. 


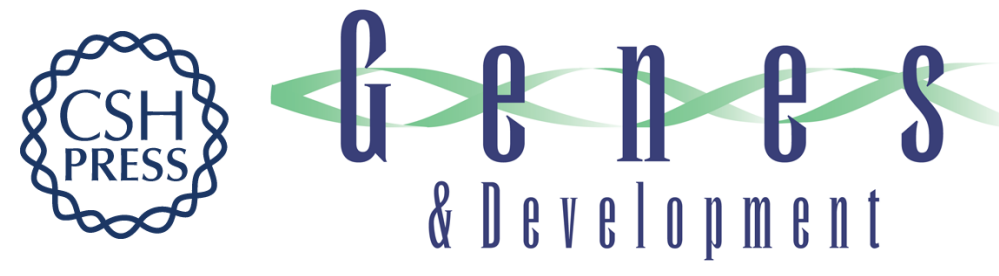

\section{Myc family oncoproteins function through a common pathway to transform normal cells in culture: cross-interference by Max and trans-acting dominant mutants.}

B Mukherjee, S D Morgenbesser and R A DePinho

Genes Dev. 1992, 6:

Access the most recent version at doi:10.1101/gad.6.8.1480

References This article cites 44 articles, 21 of which can be accessed free at: http://genesdev.cshlp.org/content/6/8/1480.full.html\#ref-list-1

License

Email Alerting Service

Receive free email alerts when new articles cite this article - sign up in the box at the top right corner of the article or click here.

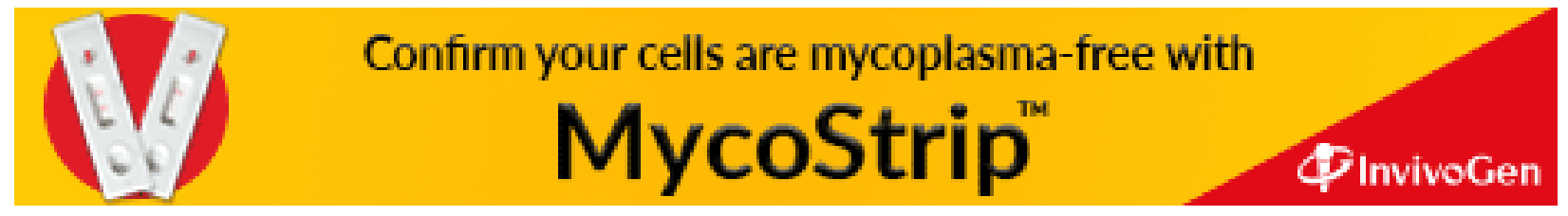

